\title{
Epidemiology of genital infections caused by Mycoplasma hominis, M. genitalium and Ureaplasma urealyticum in Iran; a systematic review and meta-analysis study (2000-2019)
}

Khadijeh Moridi ${ }^{1,2,3,4}$, Mohammad Hemmaty ${ }^{5,6}$, Amir Azimian$^{7}$, Mohammad Hosein Fallah ${ }^{8}$, Hamid Khaneghahi Abyaneh ${ }^{9,8}$ and Kiarash Ghazvini ${ }^{1,2^{*}}$ (D)

\begin{abstract}
Background: Although many species of mycoplasmas regard as normal flora, but some species causes serious genital disease. In Iran several epidemiological studies have documented the prevalence of Mycoplasma hominis, M. genitalium and Ureaplasma urealyticum in genital disorders. This meta-analysis is going to represent the prevalence of $M$. hominis, $M$. genitalium and U. urealyticum among Iranian couples and the correlation between mycoplasmas infection and infertility.

Methods: We search online databases from January 2000 to June 2019. We used following MeSH keywords (Prevalence, M. hominis, M. genitalium, U. urealyticum, male, female, fertility, Infertility, genitourinary tract infection and Iran) with all possible combinations with "OR" and "AND". Finally, forty-four articles from 2670 were chosen for data extraction and analysis by software using STATA version 14.0.

Results: This meta-analysis revealed that the prevalence of $U$. urealyticum was $17.53 \%$ in Iran and the prevalence of $M$. genitalium and $M$. hominis were 11.33 and $9.68 \%$ respectively. The rate of $M$. genitalium, $M$. hominis and $U$. urealyticum infection in women with symptoms of genitourinary tract infection was higher than men with genitourinary tract infection ( $6.46 \%$ vs $5.4,7.67 \%$ vs 5.88 and $21.04 \%$ vs $12.13 \%$, respectively). As expected, the prevalence of $M$. genitalium, $U$. urealyticum and M. hominis among infertile women (12.73, 19.58 and 10.81\%) were higher than fertile women (3\%, 10. $85 \%$ and $4.35 \%$ ). Similarly, the prevalence of $M$. hominis and U. urealyticum among infertile men (14 and 21.18\%) were higher than fertile men (4 and 3\%). Based on this analysis, the rate of $U$. urealyticum was higher than $M$. genitalium and $M$. hominis among infertile men and women compared to the fertile group. The prevalence rate of $M$. genitalium, $M$. hominis and $U$. urealyticum in central provinces is higher than other parts of Iran.
\end{abstract}

(Continued on next page)

\footnotetext{
* Correspondence: Ghazvinik@mums.ac.ir

'Department of Microbiology and Virology, Faculty of Medicine, Mashhad University of Medical Sciences, Mashhad, Iran

${ }^{2}$ Antimicrobial Resistance Research Center, Buali Research Institute, Mashhad University of Medical Sciences, Mashhad, Iran

Full list of author information is available at the end of the article
}

C C The Author(s). 2020 Open Access This article is licensed under a Creative Commons Attribution 4.0 International License, which permits use, sharing, adaptation, distribution and reproduction in any medium or format, as long as you give appropriate credit to the original author(s) and the source, provide a link to the Creative Commons licence, and indicate if changes were made. The images or other third party material in this article are included in the article's Creative Commons licence, unless indicated otherwise in a credit line to the material. If material is not included in the article's Creative Commons licence and your intended use is not permitted by statutory regulation or exceeds the permitted use, you will need to obtain permission directly from the copyright holder. To view a copy of this licence, visit http://creativecommons.org/licenses/by/4.0/ The Creative Commons Public Domain Dedication waiver (http://creativecommons.org/publicdomain/zero/1.0/) applies to the data made available in this article, unless otherwise stated in a credit line to the data. 
(Continued from previous page)

Conclusions: This meta-analysis reemphasizes a significant relationship between the infertility rate and $U$. urealyticum, $M$. genitalium and $M$. hominis infections. Our finding help to plan the prevalence map of $M$. hominis, M. genitalium and U. urealyticum in Iran but further studies are needed to suggest routine screening of the pathogens.

Keywords: Mycoplasma hominis, M. Genitalium, Ureaplasma urealyticum, Infertility, Iran

\section{Background}

Mycoplasma and Ureaplasma geniuses are the smallest self-replicating organism that belong to the Mollicutes class [1-4]. They live as external parasites of the human, animal, bird, insect and plant cells. Some species have a free-living existence in soil and water [5]. Since Dienes and Edsall isolated first mycoplasma from human in a Bartholin's gland abscess in 1937, seventeen species of human mycoplasmas species have been identified [6, 7]. As a new derivative genus Ureaplasma is divided in to 14 known serotypes and two biovars: $U$. parvum and $U$. urealyticum. U. urealyticum can be transmitted in different ways, including directly by sexual transmission, vertically from mother to offspring, or through transplanted tissues [8-13]. Generally, genital mycoplasmas such as $M$. hominis, M. genitalium and $U$. urealyticum are important emerging sexually transmitted bacterial pathogens capable to cause asymptomatic, long-term and chronic infection in genitourinary tract which is considered to be a threat to community health $[14,15]$. In a clinical study, about $40 \%$ of infants born from infected mothers with genital Mycoplasma infection had symptomatic infection such as neonatal conjunctivitis and meningitis by an ascending route or by crossing the placenta from the mother's blood via delivery through a colonized birth canal [16].

Despite the worldwide incidence of genital mycoplasmas infections, there are no accurate reports of prevalence, common types, common routes of transmission and antibiotic resistance patterns of M. genitalium, $M$. hominis and $U$. urealyticum in Iran [17]. There are some studies about the presence of genital mycoplasmas among men, women, pregnant, newborns, infertile and etc in Iran. In this systematic review and meta-analysis, we are going to present an illustration of prevalence of $M$. hominis, $M$. genitalium, and $U$. urealyticum in Iran and the correlation between mycoplasmas infection and infertility in Iranian couples.

\section{Methods}

\section{Search strategy}

We search online databases including Pubmed, Scopus, Science Direct, IranMedex, SID (Scientific Information Database), and Google Scholar for the papers that were performed in Iran from January 2000 to June 2019. We used following MeSH keywords (Prevalence, M. hominis,
M. genitalium, $U$. urealyticum, male, female, fertility, Infertility, genitourinary tract infection and Iran) with all possible combinations with "OR" and "AND". Then the titles of the articles were entered into Mendeley software to find similar articles. Difinition of terms were considered as WHO recommended. One of the limitations of this study is the lack of data in some part of Iran. Since different researchers worked on different samples and conditions, the data was categorized in six groups: 1 . Fertile men 2. Infertile men 3. Men with urinary tract infection or prostatitis 4. Fertile women 5. Infertile women 6. Women with urogenital infection or abortion or pregnant.

\section{Inclusion and exclusion criteria}

Inclusion criteria of this study consisted of a reference to the prevalence of M. genitalium, M. hominis, and $U$. urealyticum in Iranian men and women by culture and PCR. Exclusion criteria were irrelevance or limited information, countries other than Iran, review articles, methods other than culture and PCR. At the end, 44 articles, which met our inclusion criteria, were conducted for meta- analysis.

\section{Data extraction}

The data were extraction by a pre-prepared checklist from all included articles. The checklist included the author's name, year of the study, the location, sample volume, type of specimen and the prevalence of $M$. genitalium, $M$. hominis, and $U$. urealyticum. The studies on each Mycoplasma species were further categorized into subgroups, considering (1) study population according to gender (men and women) fertile, infertile and urogenital tract infection; (2) Analytical method (including PCR, and culture); (3) geographical region of sampling (including Eastern provinces: Kerman, North Khorasan, Razavi Khorasan, South Khorasan, Sistan and Baluchestan, and Yazd Provinces; Middle provinces (Northern, Central \& Southern): Alborz, Golestan, Mazandaran, Qazvin, Qom, Semnan, Tehran, Bushehr, Chaharmahal and Bakhtiari, Fars, Hormozgan, Isfahan, Kohgiluyeh and Boyer-Ahmad Provinces; Western provinces: Ardabil, East Azerbaijan, Gilan, Kordestan, West Azerbaijan, Zanjan, Hamadan, Ilam, Kermanshah, Khuzestan, Lorestan and Markazi Provinces). 


\section{Analytic approach}

The ratio of positive samples to total samples was defined as prevalence. Meta-analysis was conducted by STATA version 14 for prevalence of each bacterium on available data. Chi-squared (Q) and I-squared tests were used to assess heterogeneity among the studies. Since the heterogeneity was statistically significant ( $p$-value of $\mathrm{Q}$ test $<0.1$ and $I^{2}$ index $>75 \%$ ), a random-effects model was used; The outcome was estimated as prevalence and 95\% confidence intervals $(\mathrm{CI})$.

\section{Results}

\section{Description of included and excluded studies}

Initially 11,345 articles were identified through database searching. About 2670 articles were remained after discarding duplicate papers based on title and abstract. From 2670 articles, we excluded further 1606 papers based on exclusion criteria (489 papers on M. genitalium, 595 papers on $M$. hominis, and 522 papers on $U$. urealyticum were excluded). Forty-four original articles (full texts) related to prevalence of $M$. genitalium, $M$. hominis, and $U$. urealyticum in Iranian men and women in our literature review remained for reviewing and assessing for eligibility criteria. The final 44 articles were included: M. genitalium [17], M. hominis [18], U. urealyticum [19] with some of them contains two [15] or three [2] of these bacteria (Fig. 1). Table 1 provides an overview of the eligible studies.

\section{Prevalence of $M$. genitalium}

The overall prevalence of $M$. genitalium was $16.60 \%$ (CI 95\%; $12.01-21.18 \%)$ and $8.26 \%(\mathrm{CI} 95 \%$; $6.33-10.19 \%)$ in male and female respectively (Table 2 ).

\section{Prevalence of $M$. hominis}

The overall prevalence of $M$. hominis was $10.73 \%$ (CI 95\%; 6.77-14.69\%) and 8.83\% (CI 95\%; 6.67-10.98\%), among male and female respectively (Table 3 ).

\section{Prevalence of $U$. urealyticum}

The prevalence of $U$. urealyticum was $13.92 \%$ (CI 95\%; 7.58-20.26\%) and $19.43 \%$ (CI 95\%; 11.56-27.30\%), in male and female respectively (Table 4 ).

The prevalence rates of genital mycoplasma infection are due to $U$. urealyticum, $M$. genitalium and $M$. hominis respectively, in Iran. This study shows that the rate of $U$. urealyticum, $M$. genitalium and $M$. hominis infection in women with symptoms of genitourinary tract infection was higher than men with genitourinary tract infection. The result indicated that the prevalence of $U$. urealyticum, $M$. genitalium and $M$. hominis in infertile women were higher than fertile women. However, the prevalence of $U$. urealyticum and $M$. hominis in infertile men were higher than fertile men.

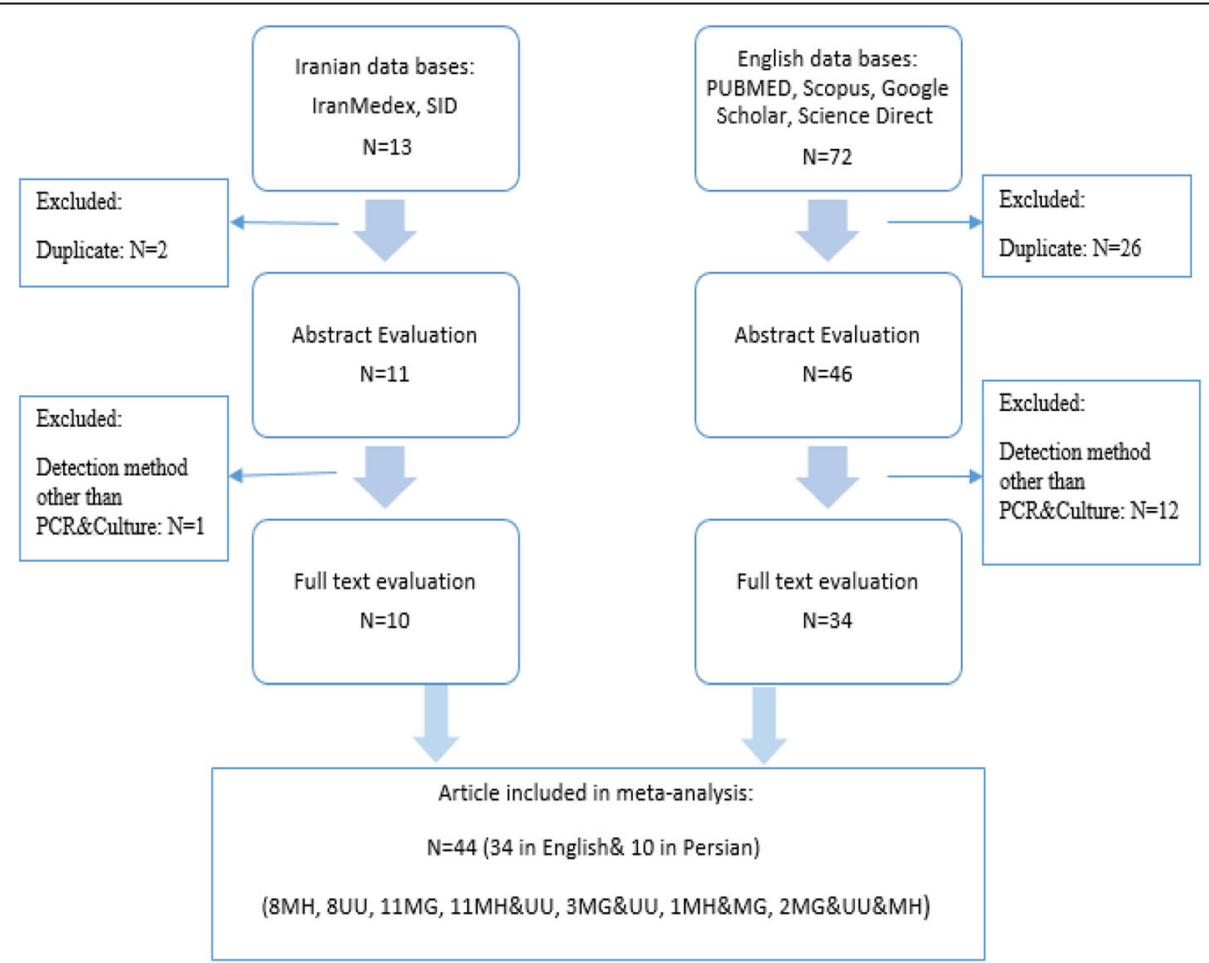

Fig. 1 Flow chart of the literature search, systematic review and study selection 


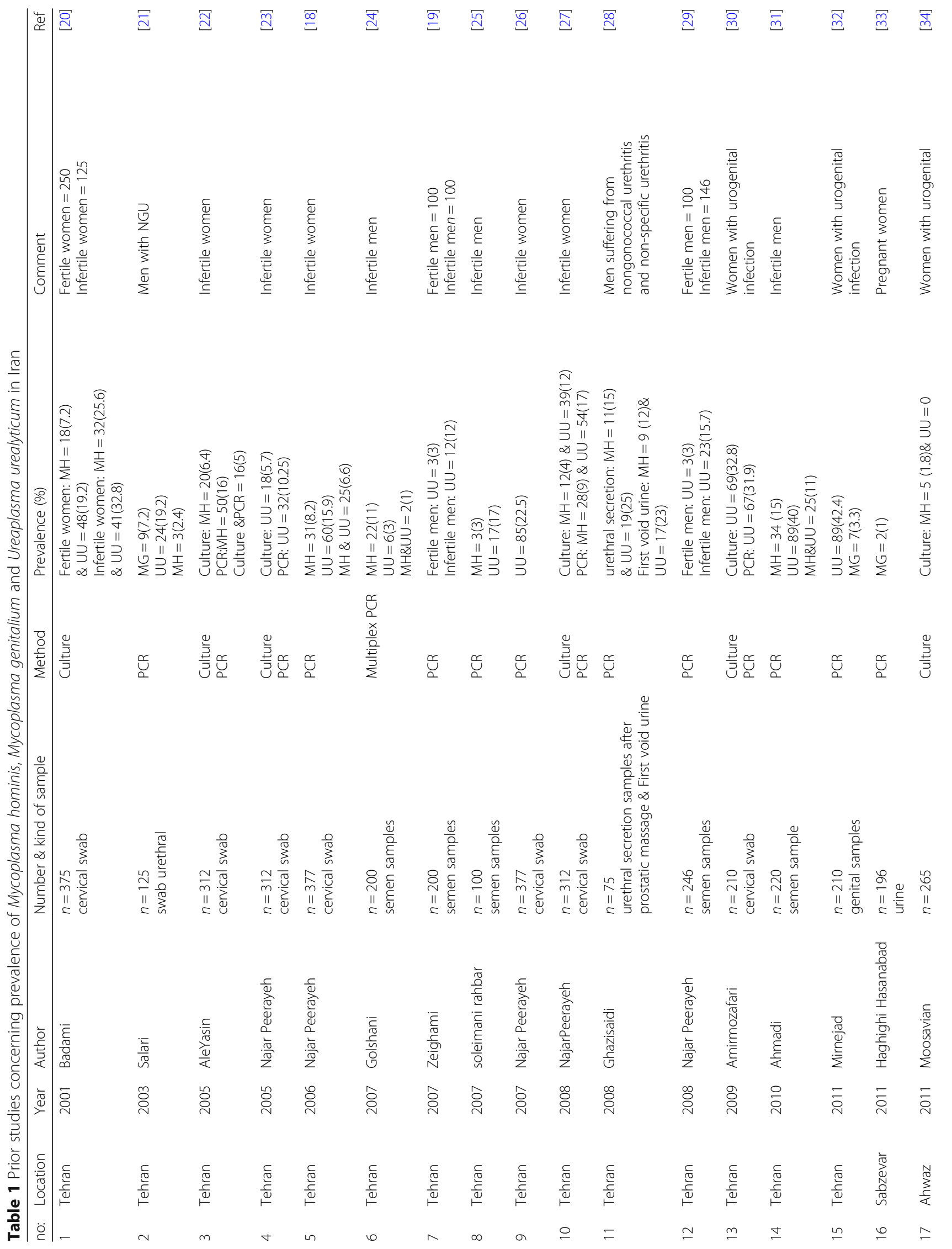




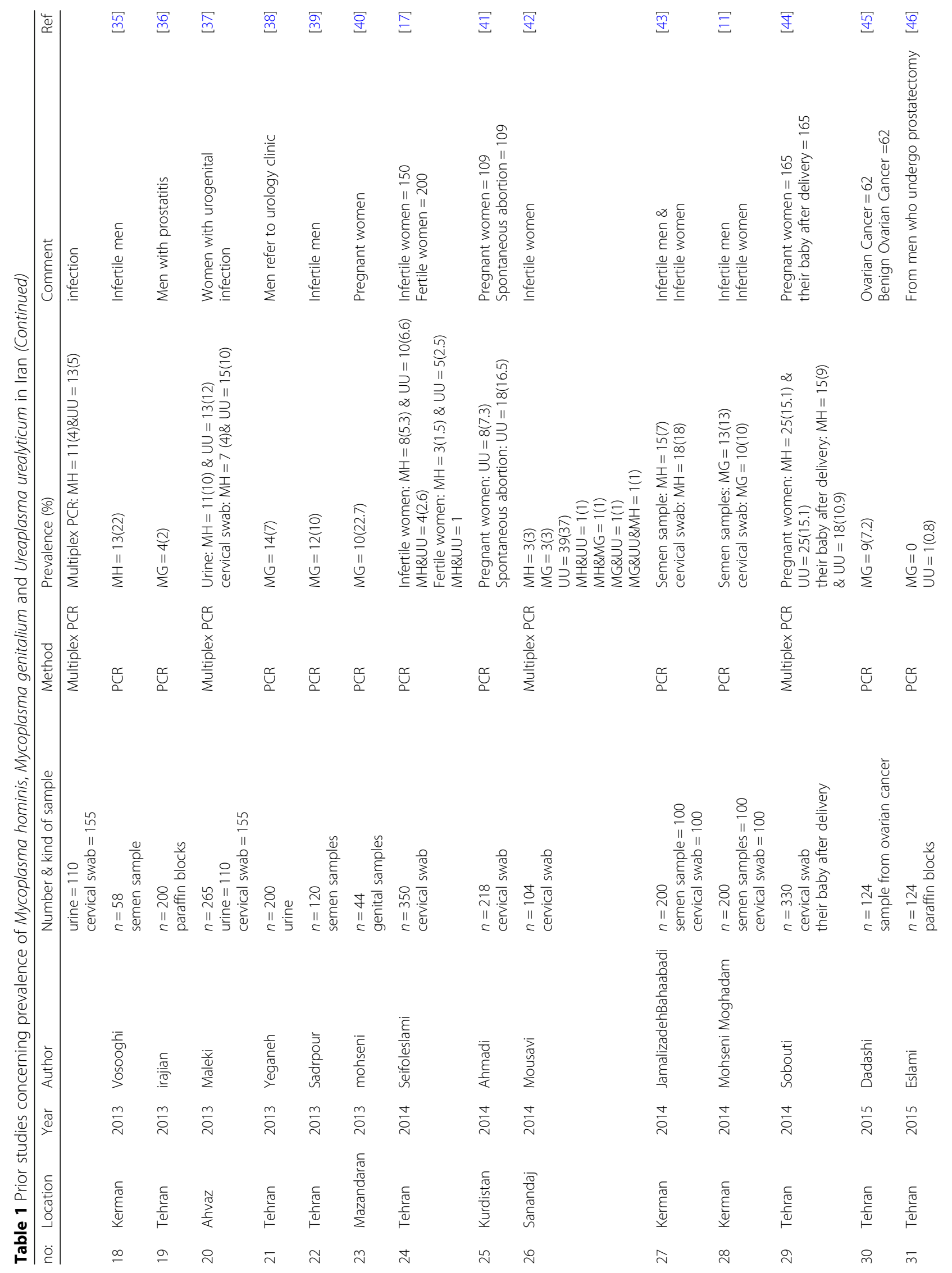


Moridi et al. BMC Public Health $\quad$ (2020) 20:1020

Page 6 of 13

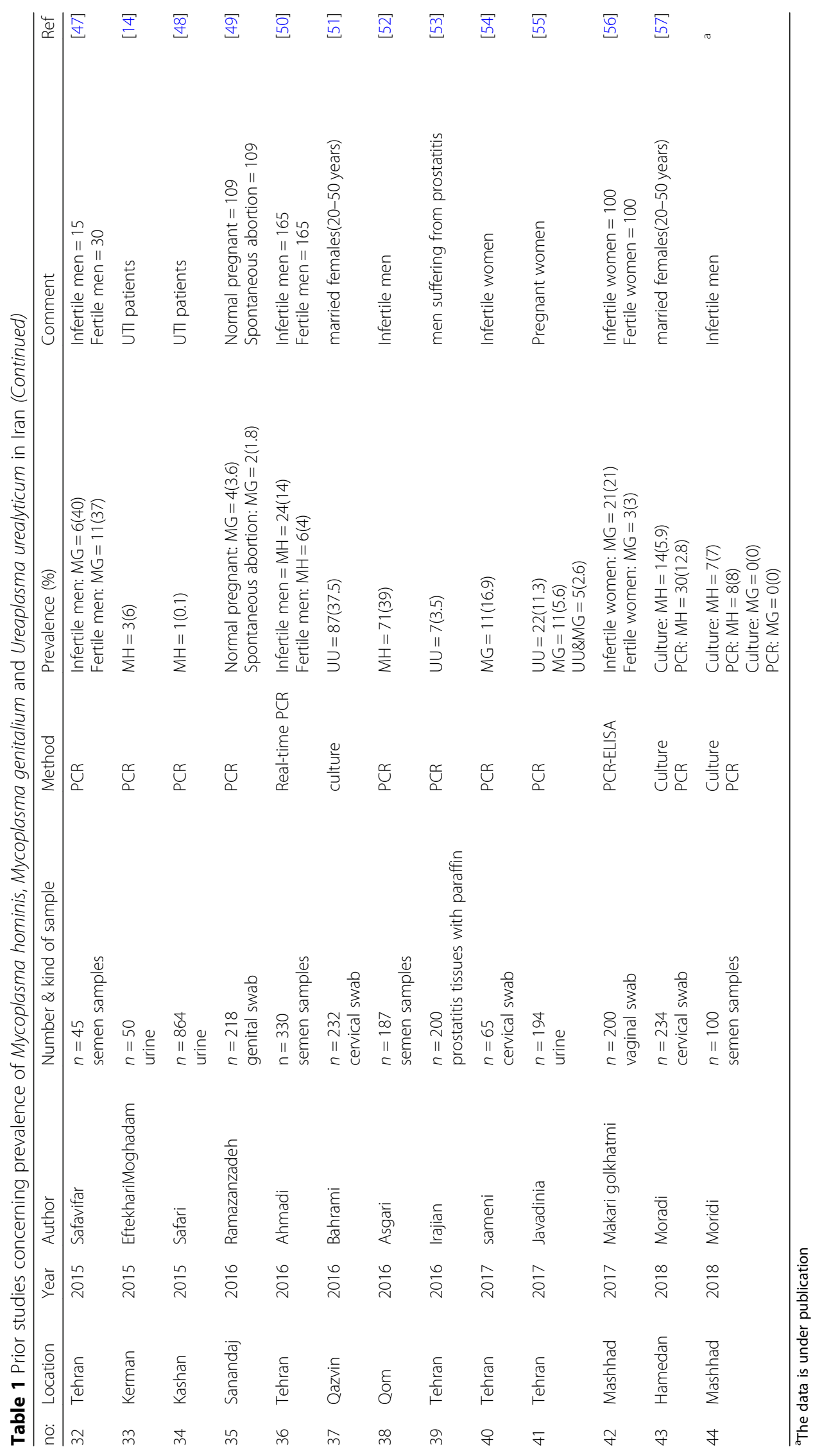


Table 2 The prevalence of M. genitalium in Iran based of metaanalysis

\begin{tabular}{|c|c|c|c|c|}
\hline Study Population & studies & sample & prevalence, 95\% Cl & Model \\
\hline Men & 8 & 1114 & $16.60,12.01-21.18$ & Random \\
\hline Fertile & 1 & 30 & $37.00,36.83-37.17$ & Random \\
\hline Infertile & 4 & 435 & $21.00,13.18-28.82$ & Random \\
\hline Symptomatic ${ }^{\prime}$ & 4 & 649 & $5.40,1.55-9.25$ & Random \\
\hline Women & 11 & 1455 & $8.26,6.33-10.19$ & Random \\
\hline Fertile & 1 & 100 & $3.00,2.97-3.03$ & Random \\
\hline Infertile & 4 & 369 & $12.73,4.44-21.01$ & Random \\
\hline Symptomatic $^{2}$ & 7 & 986 & $6.46,4.62-8.29$ & Random \\
\hline Women and men & 18 & 2569 & $11.33,9.58-13.08$ & Random \\
\hline
\end{tabular}

1. Men with urinary tract infection or prostatitis; 2 . Women with urogenital infection or abortion or pregnant

\section{Geographical distribution of $M$. hominis, M. genitalium} and $U$. urealyticum in Iran

In Eastern provinces of Iran, the prevalence of $M$. genitalium and M. hominis were 9.60 and $9.73 \%$ respectively based of meta-analysis (CI 95\%). There is no documented study on $U$. urealyticum in Eastern provinces. In Middle provinces, the prevalence of $M$. genitalium, $M$. hominis and $U$. urealyticum were 13.39, 11.17 and $17.94 \%$ respectively. While in Western provinces of Iran, the prevalence of M. genitalium, M. hominis and $U$. urealyticum were $3.3,5.65$ and $14.98 \%$ respectively (Table 5 ).

\section{Analytical method}

The forty- four selected articles which met our inclusion criteria were analyzed according to the culture and PCR methods. The prevalence rate of M. hominis and M. genitalium base on PCR (10.13\%\&11.33\%) was higher than culture method $(8.27 \% \& 0 \%)$, whereas that was contrary in $U$. urealyticum (Figs. 2, 3 and 4).

Table 3 The prevalence of M. hominis in Iran based of metaanalysis

\begin{tabular}{|c|c|c|c|c|}
\hline Study Population & studies & sample & prevalence, 95\% Cl & Model \\
\hline Men & 12 & 2344 & $10.73,6.77-14.69$ & Random \\
\hline Fertile & 1 & 165 & $4.00,3.97-4.03$ & Random \\
\hline Infertile & 7 & 1130 & $14.00,7.45-20.55$ & Random \\
\hline Symptomatic ${ }^{\prime}$ & 4 & 1049 & $5.88,2.18-9.57$ & Random \\
\hline Women & 12 & 3670 & $8.83,6.67-10.98$ & Random \\
\hline Fertile & 2 & 450 & $4.35,-1.24-9.94$ & Random \\
\hline Infertile & 7 & 1480 & $10.81,7.18-14.45$ & Random \\
\hline Symptomatic $^{2}$ & 3 & 1740 & 7.67, 4.34-10.99 & Random \\
\hline Women and men & 22 & 6014 & $9.68,7.75-11.61$ & Random \\
\hline
\end{tabular}

1. Men with urinary tract infection or prostatitis; 2 . Women with urogenital infection or abortion or pregnant
Table 4 The prevalence of $U$. urealyticum in Iran based of metaanalysis

\begin{tabular}{|c|c|c|c|c|}
\hline Study Population & studies & sample & prevalence, 95\% Cl & Model \\
\hline Men & 8 & 1290 & $13.92,7.58-20.26$ & Random \\
\hline Fertile & 2 & 200 & $3.00,2.98-3.02$ & Random \\
\hline Infertile & 4 & 766 & $21.18,8.61-33.74$ & Random \\
\hline Symptomatic $^{\prime}$ & 4 & 324 & $12.13,3.23-21.02$ & Random \\
\hline Women & 14 & 4441 & $19.43,11.56-27.30$ & Random \\
\hline Fertile & 2 & 450 & $10.85,-5.52-27.22$ & Random \\
\hline Infertile & 7 & 1757 & $19.58,13.59-25.57$ & Random \\
\hline Symptomatic $^{2}$ & 5 & 2234 & $21.04,8.95-33.13$ & Random \\
\hline Women and men & 24 & 5731 & $17.53,11.40-23.66$ & Random \\
\hline
\end{tabular}

1. Men with urinary tract infection or prostatitis; 2 . Women with urogenital infection or abortion or pregnant

\section{Discussion}

The epidemiology and role of $M$. hominis, M. genitalium and $U$. urealyticum in infertility has been less discussed in Iran [14]. The different reports documented in other countries around the world. M. genitalium has been identified as a causative agent of $10-35 \%$ nongonococcalnonchlamydia urethritis [58-62]. According to the community-based prospective cohort study from Oakeshott (2010) M. genitalium is found in 0.7 to $3.3 \%$ of women in general populations, while the prevalence in high-risk groups such as sex workers and STD clinic attendees is $7-22 \%$ in London [5, 63]. However, M. hominis resides commensally on the mucosal surfaces of the cervix or vagina. It's colonization values ranges between 20 and $30 \%$ around the world $[48,64] . M$. hominis was detected in $21-53 \%$ of women without genitourinary tract infection and at a lower percentage in the urethra of male [1]. Several studies have proposed that $M$. hominis is potentially pathogenic and sometimes associated with a variety of disorders including bacterial vaginosis, pyelonephritis, pelvic inflammatory disease, chorioamnionitis, endometritis, preterm birth, low birth, spontaneous abortion, stillbirth, premature birth, postpartum fever, perinatal mortality and infertility overtime $[65,66]$. The positive rates of M. hominis, $M$. genitalium and $U$. urealyticum are controversial and diverse in the world [67]. Recently, Ghadiri (2019) in Iran (Ahwaz) detected $U$. urealyticum (28\%) and M. hominis $(10 \%)$ in semen specimens of infertile men by PCR and isolated $22 \%$ of $U$. urealyticum and $2 \%$ of $M$. hominis in the same samples by culture. While, $U$. urealyticum and $M$. hominis were detected in $50 \%$ \& $26 \%$ by PCR of endocervical swabs specimens of infertile women and $8 \%$ \& $4 \%$ by culture [68]. Christian Leli (2018) was detected $U$. urealyticum in $4.7 \%$, M. hominis in $3.4 \%$ and M.genitalium in $0 \%$ of 232 cervical swab specimens of infertile women by real-time PCR in Italy [69]. Xiaofei Zhu (2016) showed that the prevalence of $U$. urealyticum and $M$. hominis were 42.3 and $0.4 \%$ among 7374 infertile men by culture 
Table 5 The prevalence and 95\% Cl of Mycoplasma hominis, Mycoplasma genitalium and Ureaplasma urealyticum in different regions of Iran based of meta-analysis

\begin{tabular}{|c|c|c|c|c|c|c|}
\hline \multirow[t]{2}{*}{ Study Location } & \multicolumn{2}{|l|}{ M. genitalium } & \multicolumn{2}{|l|}{ M. hominis } & \multicolumn{2}{|l|}{ U. urealyticum } \\
\hline & provinces (studies) & prevalence, $95 \% \mathrm{Cl}$ & provinces (studies) & prevalence, 95\% Cl & provinces (studies) & prevalence, 95\% Cl \\
\hline Eastern provinces ${ }^{1}$ & $2(4)$ & $9.60,4.01-15.19$ & $2(5)$ & $9.73,4.49-14.96$ & 0 & - \\
\hline Middle provinces ${ }^{2}$ & $2(12)$ & $13.39,11.14-15.64$ & $2(11)$ & $11.17,8.10-14.24$ & $2(17)$ & $17.94,11.08-24.80$ \\
\hline Western provinces ${ }^{3}$ & $1(2)$ & $3.30,2.71-3.89$ & $3(4)$ & $5.65,3.09-8.22$ & $2(4)$ & $14.98,6.83-23.12$ \\
\hline
\end{tabular}

(1) Eastern provinces: Kerman, North Khorasan, Razavi Khorasan, Sistan and Baluchestan, South Khorasan and Yazd Provinces; (2) Middle provinces: (Northern Central \& southern): Alborz, Golestan, Mazandaran, Qazvin, Qom, Semnan, Tehran, Bushehr, Chaharmahal and Bakhtiari, Fars, Hormozgan, Isfahan, Kohgiluyeh and Boyer-Ahmad Provinces; (3) Western provinces: Ardabil, East Azerbaijan, Gilan, Kordestan, West Azerbaijan, Zanjan, Hamadan, Ilam, Kermanshah, Khuzestan, Lorestan and Markazi Provinces

[70]. Mahlangu (2019) was determined M. genitalium in $8.9 \%$ of urine and $10.6 \%$ of endocervical swab specimens which collected from males and females with genital discharge syndrome [71].

Baumann (2017) performed a meta-analysis on prevalence of $M$. genitalium and found that: the prevalence among women is similar to men and was $1.4 \%$ in developed countries and 3.9\% in developing countries among general population. He showed that the prevalence among pregnant women were $0.9 \%$, and the prevalence among men who have sex with men in the community was $3.2 \%$, and among female commercial sex workers

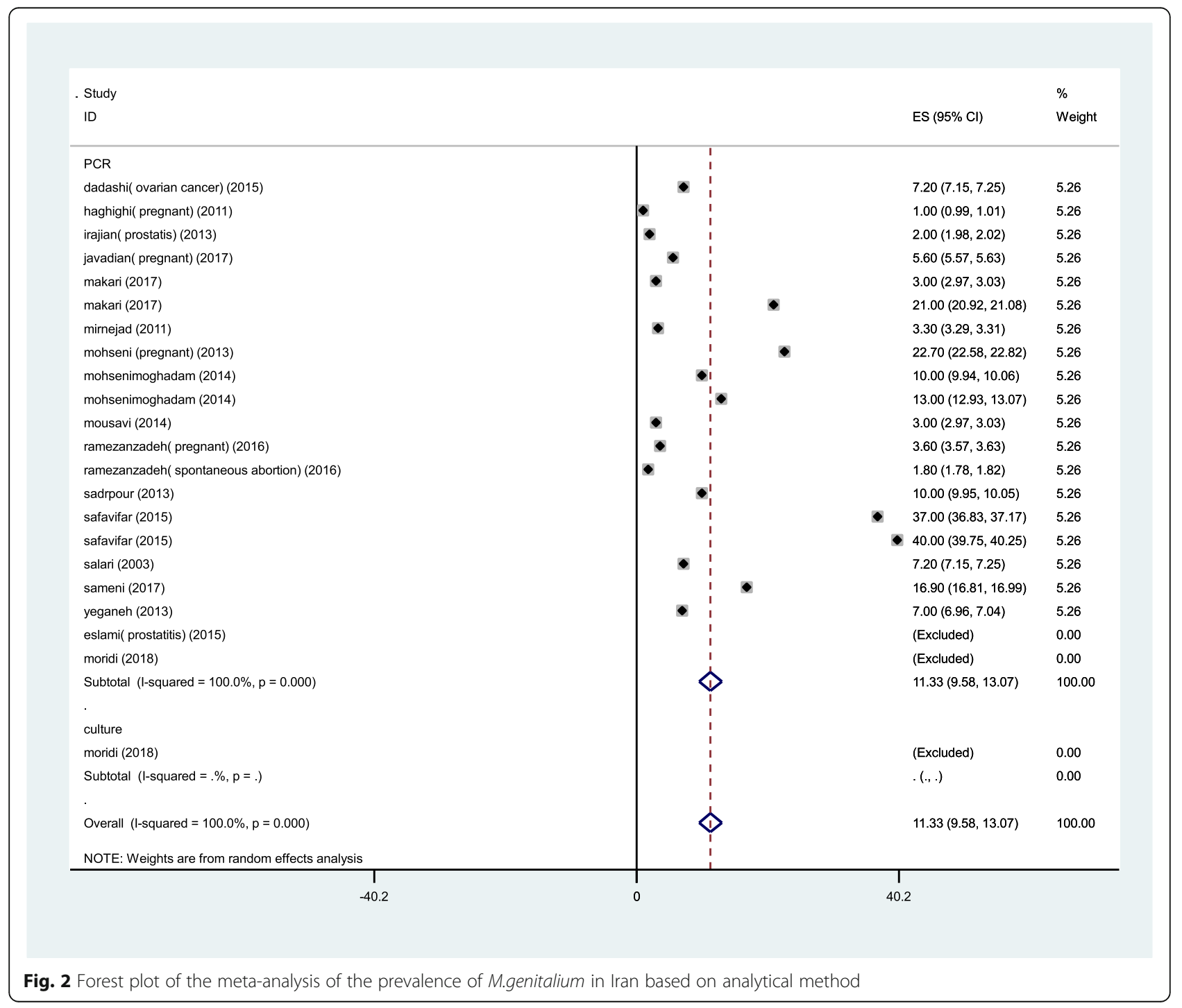




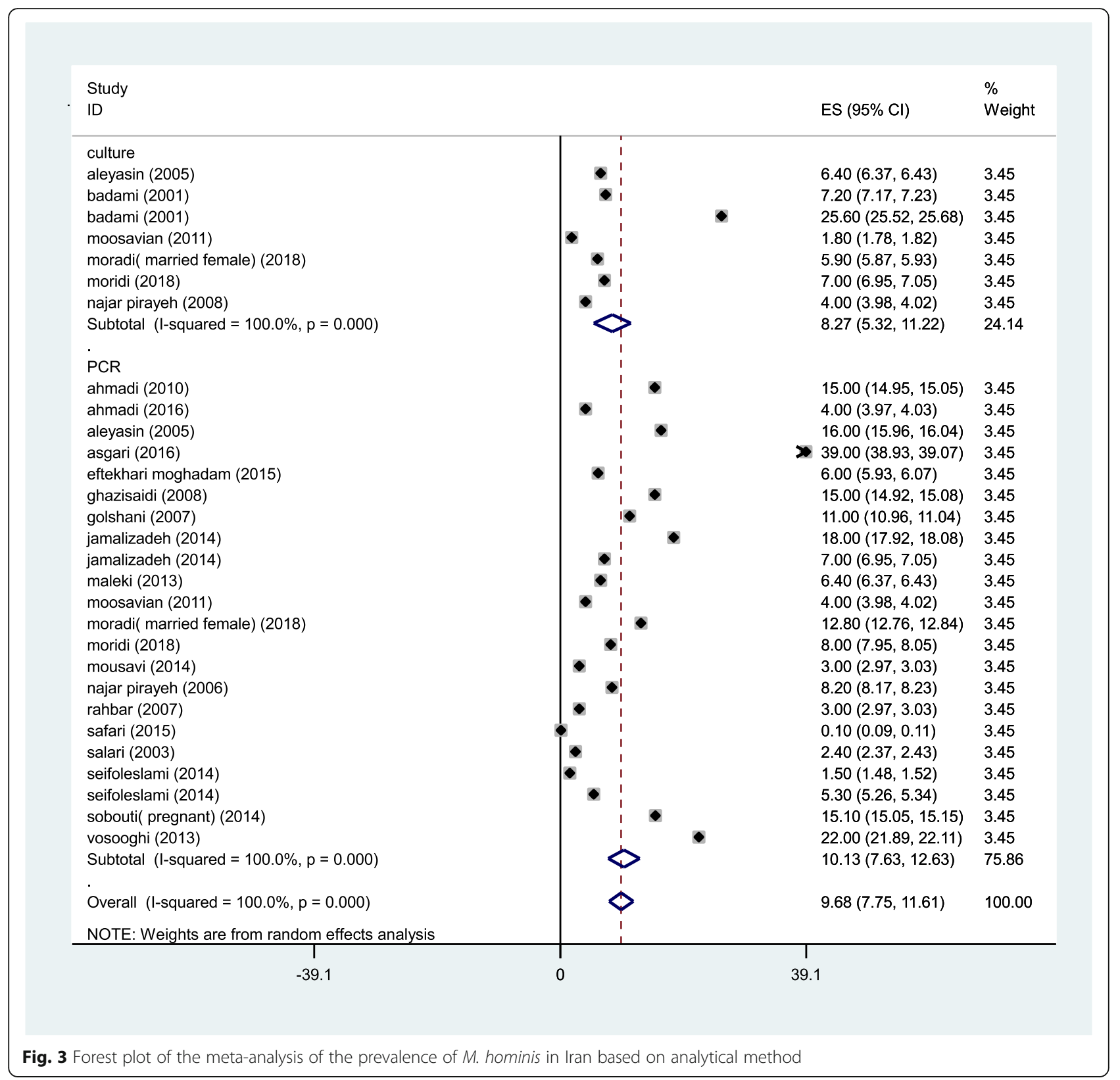

was $15.9 \%$ in the world [72]. Huang performed metaanalysis study (2015) and investigated the association between $U$. urealyticum, and $M$. hominis positive rate (5.2\% \& $14.9 \%)$ and risk of male infertility. While the $M$. genitalium prevalence did not showed any correlation to male infertility [73]. Kasprzykowska (2018) indicated that the prevalence of Ureaplasma spp in women $(14.4 \%)$ and men $(3.9 \%)$ is higher than $M$. hominis in women $(0.2 \%)$ and men $(0.2 \%)$ with urogenital tract infection in Poland [74]. Cassell estimated that the $U$. urealyticum can be found in 40 to $80 \%$ of cervicovaginal samples from sexually mature women [74, 75]. Zinzendorf (2008) investigated $M$. hominis in $23.8 \%$ of infertile men in Africa [76]. Taken (2016) could determine M. hominis in 3\% of infertile men in Turkey [77]. Abusarah (2013) detected $U$. urealyticum in $10.8 \%$ versus $5.7 \%$ and $M$. genitalium in $3.2 \%$ versus $1.4 \%$ among infertile and fertile men respectively in Jordan [78]. Jensen indicated M. genitalium in $17 \%$ of male patient with urogenital tract infection in Denmark [79]. Al- Sweih (2012) in Kuwait detected $M$. hominis in $17.1 \%$ \& $32.4 \%$, M. genitalium in $4.7 \%$ \& $3.2 \%$ and $U$. urealyticum in $24.4 \%$ \& $26.1 \%$, among infertile and fertile men respectively [80]. Lee (2013) displayed U.urealyticum in $48 \%$ \& $25 \%$, M. hominis in $14 \%$ \& $6.3 \%$ of infertile and fertile men, while, $U$. urealyticum in $40 \%$ \& $22.9 \%$ and M. hominis in $8 \%$ \& $4.2 \%$ of infertile and fertile women in Korea [81]. Andersen reported that the prevalence of infection due to M. genitalium in general 


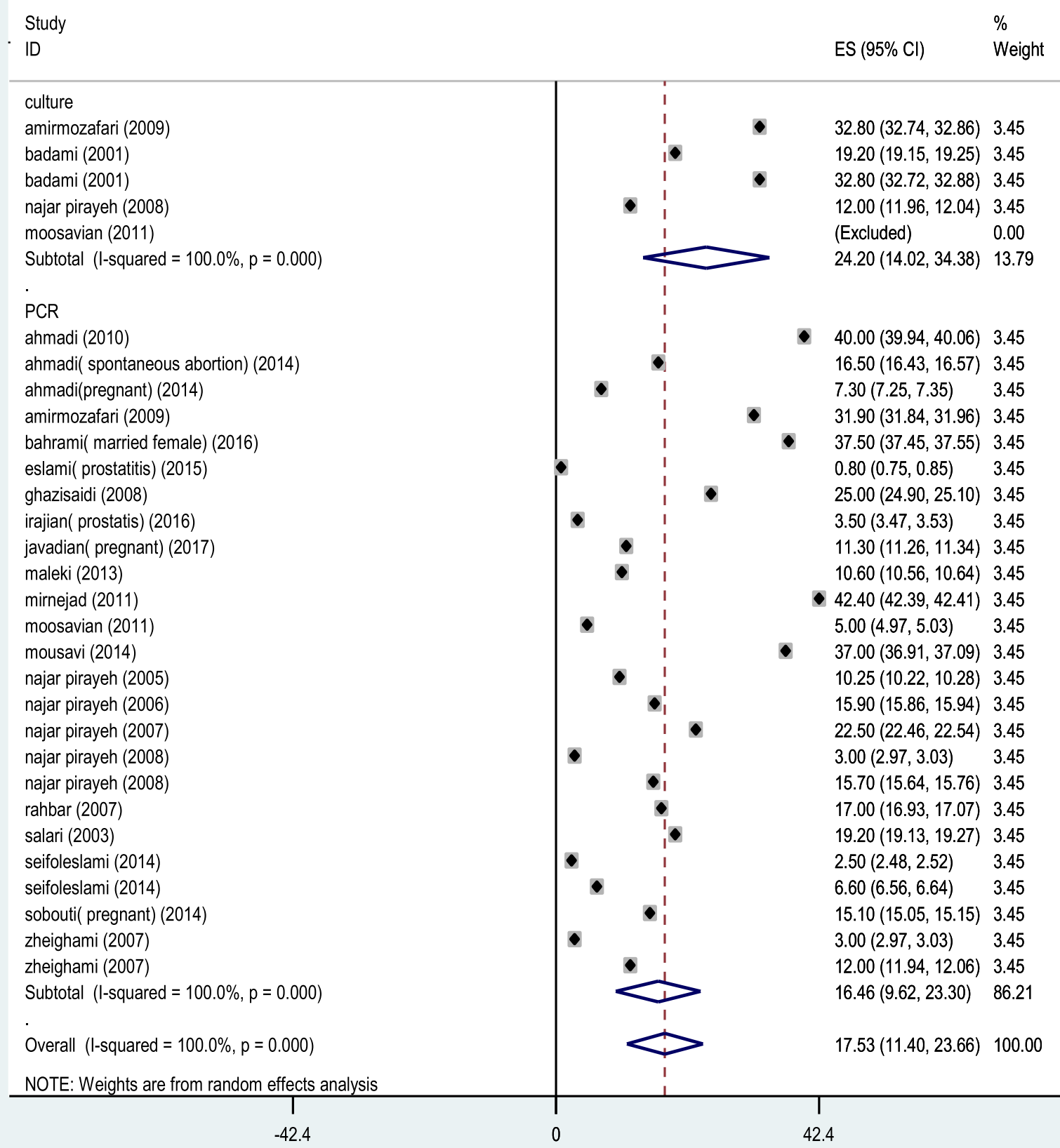

Fig. 4 Forest plot of the meta-analysis of the prevalence of U. urealyticum in Iran based on analytical method

population was $2.3 \%$ in women and $1.1 \%$ in men whereas that was about $19 \%$ in men with urethritis and $11 \%$ in women with cervicitis in Denmark [82]. Also Grześko indicated M. genitalium from $19.6 \%$ of specimens obtained from cervical canal of infertile women, whereas it was $4.4 \%$ in control group (women with proven fertility) in Poland [83].
The prevalence rates of Mycoplasma and Ureaplasma are not well established and varies from one study to another. The heterogeneity of prevalence of mycoplasma urinary tract infection in different reports can be probably caused by differences in the geographic areas, the sensitivity of the identification method, the condition of the group (fertile/infertile), 
other infection accompanied agents, the sample size, and the operator proficiency.

Based on present meta-analysis study the prevalence rates of genital Mycoplasma infection are due to $U$. urealyticum (17.53\%), M. genitalium (11.33\%) and $M$. hominis $(9.68 \%)$ respectively in Iran which is parallel to Christian Leli (Italy) and Xiaofei (China) results. According to other researcher results, this study shows that the rate of $M$. genitalium, $M$. hominis and $U$. urealyticum infections in women with symptoms of genitourinary tract infection is higher than men with genitourinary tract infection (6.46\% Vs 5.4, 7.67\% Vs 5.88 and $21.04 \%$ Vs $12.13 \%$, respectively). That is in line with kasprzykowska and Mahlangu results. Iranian researches indicated that the prevalence of $M$. genitalium, $U$. urealyticum and $M$. hominis among infertile women $(12.73,19.58$ and $10.81 \%)$ are higher than fertile women $(3 \%, 10.85 \%$ and $4.35 \%)$, which is similar to Lee $(2013)$ report. However, the prevalence of $M$. hominis and $U$. urealyticum in infertile men (14 and $21.18 \%$ ) is higher than fertile men (4 and 3\%), which is like Lee (2013) result.

According to analysis result, the prevalence of M. genitalium, $M$. hominis and $U$. urealyticum in Middle provinces is higher than other provinces in Iran. This may be due to the presence of infertility centers and specialized STD clinics in the capital of the country; Tehran. There are some different diagnostic equipment and facilities to research and attract infertile couples for treatment all over Iran.

\section{Conclusions}

Based on our meta-analysis, the most common Mycoplasma in Iran, in descending order are: $U$. urealyticum, M. genitalium, and M. hominis. There is statistically significant relationship between couple infertility and $U$. urealyticum, $M$. genitalium and $M$. hominis infections. There is the higher rate of mycoplasmas infection in women than men and their correlated infertilities.

However, obstetricians should consider mycoplasmas infection as a major agent of infertility. Since mycoplasmas are resistant to common antibiotics and the high prevalence of some mycoplasmas like $U$. urealyticum, Iranian physicians should be careful in the treatment of genitourinary tract infections to the possible presence of mycoplasmas agent and the sensitive antibiotics.

Further epidemiological and phylogenetic studies in different provinces will be needed to clarify the exact prevalence and distribution pattern of $U$. urealyticum, $M$. genitalium and M. hominis in Iran, and proposed routine screening of the pathogens in patients with infertility.
Abbreviations

M: Mycoplasma; U: Ureaplasma; PCR: polymerase chain reaction

Acknowledgements

We gratefully acknowledge the help provided by Branch Razi Vaccine and Serum Research Institute, Agricultural Research, Education and Extension Organization (AREEO), Mashhad, Iran; and Department of Microbiology and Virology, Faculty of Medicine, Mashhad University of Medical Sciences, Mashhad, Iran.

\section{Authors' contributions}

MK \& HM collected information from database and writing the article. FMH and $\mathrm{KAH}$ performed Meta-analysis and interpretation. HM and AA and GK contributed to the design of the study and supervised the research. The author(s) read and approved the final manuscript.

\section{Funding}

No funding was obtained for this study.

Availability of data and materials

Not applicable.

Ethics approval and consent to participate

Not applicable.

\section{Consent for publication}

Not applicable.

\section{Competing interests}

No conflicts of interest are declared.

\section{Author details}

${ }^{1}$ Department of Microbiology and Virology, Faculty of Medicine, Mashhad University of Medical Sciences, Mashhad, Iran. ${ }^{2}$ Antimicrobial Resistance Research Center, Buali Research Institute, Mashhad University of Medical Sciences, Mashhad, Iran. ${ }^{3}$ Vice Chancellory for Health, Mashhad University of Medical Sciences, Mashhad, Iran. ${ }^{4}$ Student Research Committee, Mashhad University of Medical Sciences, Mashhad, Iran. ${ }^{5}$ Branch Razi Vaccine and Serum Research Institute, Agricultural Research, Education and Extension Organization (AREEO), Mashhad, Iran. ${ }^{6}$ Salim Immune Production Co.Technology Incbator of Razi Vaccine and Serum Research Institute, Ahmad abad str, Mashhad, Iran. ${ }^{7}$ Department of Microbiology, Faculty of Medicine, North Khorasan University of Medical Sciences, bojnurd, Iran. ${ }^{8}$ Branch Razi Vaccine and Serum Research Institute, Agricultural Research, Education and Extension Organization (AREEO), Tehran, Iran. ${ }^{9}$ Department of Food Hygiene and Quality control, Faculty of Veterinary Medicine, University of Tehran, Tehran, Iran.

Received: 1 September 2019 Accepted: 19 May 2020

Published online: 29 June 2020

\section{References}

1. Jironkin A, Brown RJ, Underwood A, Chalker VJ, Spiller OB. Genomic determination of minimum multi-locus sequence typing schemas to represent the genomic phylogeny of Mycoplasma hominis. BMC Genomics. 2016;17(1):16

2. Bébéar CM, Pereyre S. Infections à « Mycoplasma hominis ». EMC - Mal Infect. 2004;1(1):1-6 Available from: http://linkinghub.elsevier.com/retrieve/ pii/S1166859802000807.

3. Wolf M, Müller T, Dandekar T, Pollack JD. Phylogeny of Firmicutes with special reference to Mycoplasma (Mollicutes) as inferred from phosphoglycerate kinase amino acid sequence data. Int J Syst Evol Microbiol. 2004:54(3):871-5.

4. Weisburg WG, Tully JG, Rose DL, Petzel JP, Oyaizu H, Yang D, et al. A phylogenetic analysis of the mycoplasmas: basis for their classification. J Bacteriol. 1989:171(12):6455-67.

5. Lokken E. Recent bacterial vaginosis is associated with the acquisition of Mycoplasma genitalium: University of Washington; ProQuest; 2015.

6. Zhang S, Tsai S, Wu TT, Li B, Shih JW-K, Lo S-C. Mycoplasma fermentans infection promotes immortalization of human peripheral blood mononuclear cells in culture. Blood. 2004;104(13):4252-9 Available from: 
http://www.ncbi.nlm.nih.gov/pubmed/15331449\%5Cn, http://www. bloodjournal.org/cgi/doi/10.1182/blood-2004-04-1245.

7. Hayflick L, Chanock RM. Mycoplasma species of man. Bacteriol Rev. 1965; 29(2):185-221.

8. Sweeney EL, Dando SJ, Kallapur SG, Knox CL. The human Ureaplasma species as causative agents of chorioamnionitis. Clin Microbiol Rev. 2017; 30(1):349-79.

9. Zarei O, Rezania S, Mousavi A. MINI-REVIEW Mycoplasma genitalium and Cancer : a brief review. Asian Pac J Cancer Prev. 2013;14:3425-8.

10. Ahmadi MH, Mirsalehian A, Bahador A. Prevalence of Urogenital Mycoplasmas in iran and their effects on fertility potential. Syst Rev MetaAnal. 2016:45(4):409-22.

11. Moghadam NM, Kheirkhah B, Mirshekari TR, Harandi F, Tafsiri E. Isolation and molecular identification of Mycoplasma genitalium from the secretion of genital tract in infertile male and female. Iran J Reprod Med. 2014;12(9):601-8.

12. Haghighi Hasanabad M, Mohammadzadeh M, Bahador A, Fazel N, Rakhshani H, Majnooni A. Prevalence of Chlamydia trachomatis and Mycoplasma genitalium in pregnant women of Sabzevar-Iran. Iran J Microbiol. 2011;3(3):123-8.

13. Jensen JS, Cusini M, Gomberg M, Moi H. Background review for the 2016 European guideline on Mycoplasma genitalium infections. J Eur Acad Dermatology Venereol. 2016;30(10):1686-93 Available from: http://doi.wiley. com/10.1111/jdv.13850.

14. Moghaddam HE, Kheirkhah B, Amirheidari B. A comparison between the molecular identity of Mycoplasma hominis in urine samples of patients with urinary tract infections and similar strains available in GenBank. J Babol Univ Med Sci. 2015;17(10):67-73.

15. Manhart LE, Holmes KK, Hughes JP, Houston LS, Totten PA. Mycoplasma genitalium among young adults in the United States: an emerging sexually transmitted infection. Am J Public Health. 2007;97(6):1118-25.

16. Stellrecht KA, Woron AM, Mishrik NG, Venezia RA. Comparison of multiplex PCR assay with culture for detection of genital Mycoplasmas. J Clin Microbiol. 2004;42(4):1528-33.

17. Seifoleslami M, Safari A, Khayyat KM. Prevalence of Ureaplasma urealyticum and Mycoplasma hominis in high vaginal swab samples of infertile females. Iran Red Crescent Med J. 2015;17(12):0-4 Available from: http://ircmj. neoscriber.org/en/articles/16257.html.

18. Sh NP, Sattari M. Detection of Ureaplasma urealyticum and Mycoplasma hominis in endocervical specimens from infertile women by polymerase chain reaction. Middle East Fertil Soc J. 2006:11(2):104-8 Available from: http://www.embase.com/search/results?subaction=viewrecord\&from= export\&id=L44788413\%5Cn, http://www.bioline.org.br/pdf?mf06020\%5Cn, http://bj7rx7bn7b.search.serialssolutions.com?sid=EMBASE\&issn=111056 90\&id=doi:\&atitle=Detection+of+Ureaplasma+urealyticum+and $+M y$.

19. Zeighami H, Sh NP, Safarlu M. Detection of Ureaplasma urealyticum in semen of infertile men by PCR. Pak J Biol Sci. 2007;10(21):3960-3.

20. Badami N. Rate of Chlamydia trachomatis, Mycoplasma hominis and Ureaplasma urealyticum in infertile females and control group. Iran J Publ Heal. 2001;30(1-2):57-60

21. Salari MH. Prevalence of Ureaplasma urealyticum and Mycoplasma genitalium in men with non-gonococcal urethritis. East Mediterr Heal J. 2003;9(3):291-5.

22. Ale YA. Comparison of PCR with culture for detection of Mycoplasma hominis in infertile women. Kowsar Med J. 2005;10(3):183-90.

23. Peerayeh SN, Mirdamadi R. Comparison of culture with polymerase chain reaction for detection of Ureaplasma urealyticum in endocervical specimens. Med J Islam Repub Iran. 2005;19(2):175-9.

24. Golshani M, Eslami G, Mohhammadzadeh Ghobadloo S, Fallah F, Goudarzi $\mathrm{H}$, Soleimani Rahbar AA, et al. Detection of Chlamydia trachomatis, mycoplasma hominis and Ureaplasma urealyticum by multiplex PCR in semen sample of infertile men. Iran J Public Health. 2007:36(2):50-7.

25. Soleimani Rahbar A, Golshani M, Fayyaz F, Rafiee Tabatabaei SMA. Detection of Mycoplasma DNA from the sperm specimens of infertile men by PCR. Iran J Med Microbiol. 2007;1 (1):47-53.

26. Najar Peerayeh S. Samimi R. Detection of Ureaplasma urealyticum in clinical samples from infertile women by polymerase chain reaction. Iran J Pharmacol Ther. 2007;6(1):23-6 Available from: http://www.embase.com/ search/results?subaction $=$ viewrecord\&from $=$ export\&id $=L 351727895 \% 5 \mathrm{Cn}$, http://ijpt.iums.ac.ir/index.php/ijpt/article/view/418/247\%5Cn, http:// bj7rx7bn7b.search.serialssolutions.com?sid=EMBASE\&issn=17352657\&id=doi: \&atitle=Detection+of+Ureapla.
27. Peerayeh SN, Samimi R. Comparison of culture with the polymerase chain reaction for detection of genital mycoplasma. Eur J Gen Med. 2008;5(2):10711 Available from: http://www.ejgm.org/index.php/EJGM/article/view/52/21.

28. Ghazisaidi K, Fateminasab F. Prostatic massage method versus first -void urine samples to isolate Mycoplasma hominis and Ureaplasma urealyticum from urinary tract infection. Spring Summer. 2008;2(1):69.

29. Sh NP, Yazdi RS, Zeighami H. Association of Ureaplasma urealyticum infection with Varicocele-related infertility. J Infect Dev Ctries. 2008;2(2): 116-9.

30. Amirmozafari N, Mirnejad R, Kazemi B, Sariri E. Comparison of polymerase chain reaction and culture for detection of genital mycoplasma in clinical samples from patients with genital infections. Saudi Med J. 2009;30(11): $1401-5$.

31. Ahmadi MH, Amirmozafari N, Kazemi B, Gilani MAS, Jazi FM. Use of PCR to detect Mycoplasma hominis and Ureaplasma urealyticum from semen samples of infertile men who referred to royan institute in 2009. Yakhteh Med J. 2010;12(3):371-80 Available from: http://www.scopus.com/inward/ record.url?eid=2-s2.0-78650502633\&partnerlD=tZOtx3y1.

32. Mirnejad R, Amirmozafari N, Kazemi B. Simultaneous and rapid differential diagnosis of Mycoplasma genitalium and Ureaplasma urealyticum based on a polymerase chain reaction-restriction fragment length polymorphism. Indian J Med Microbiol. 2011;29:33-6.

33. Hasanabad MH, Mohammadzadeh M, Bahador A, Fazel N, Rakhshani $\mathrm{H}$, Majnooni A. Prevalence of Chlamydia trachomatis and Mycoplasma genitalium in pregnant women of Sabzevar-Iran. Iran J Microbiol. 2011;3(3): 123-8 Available from: http://journals.tums.ac.ir/upload_files/pdf/_/19951.pdf.

34. Moosavian SM, Motamedi H, Maleki S, Shahbazian N. Comparison between prevalence of Mycoplasma Hominis and Ureaplasma urealyticum in women with urogenital infections by multiplex PCR and culture methods. Med J Tab Univ Med Sci. 2011;33(5):33.

35. Vosooghi S, Karimi B, Kheirkhah B, Mirshekari T. Molecular detection of Mycoplasma hominis from genital secretions of infertile men referred to the Kerman infertility center. J Microb World. 2013;6(1):14-22.

36. Irajian GR, Mirnejad R, Jalili Nidishan MR. Determing the prevalence rate of Mycoplasma genitalium in patients with prostatitis by PCR-RFLP technique. J Ardabil Univ Med Sci. 2013;13(1):86-92.

37. Maleki S, Motamedi H, Moosavian SM, Shahbaziyan N. Frequency of Mycoplasma hominis and Ureaplasma urealyticum in females with urogenital infections and habitual abortion history in Ahvaz, Iran; using multiplex PCR. Jundishapur J Microbiol. 2013;6(6):e10088.

38. Yeganeh O, Jeddi-Tehrani M, Yaghmaie F, Kamali K, Heidari-Vala H, Zeraati $\mathrm{H}$, et al. A survey on the prevalence of Chlamydia trachomatis and Mycoplasma genitalium infections in symptomatic and asymptomatic men referring to urology clinic of labbafinejad hospital, Tehran, Iran. Iran Red Crescent Med J. 2013;15(4):340-4.

39. Sadrpour P, Bahador A, Abbas S, Bagheri R, Chamani-Tabriz L. Detection of Chlamydia trachomatis and Mycoplasma genitaliumin semen samples of infertile men using multiplex PC. Tehran Univ Med J. 2013;70(10):623-9.

40. Mohseni R, Sadeghi F, Mirinargesi M. A study on the frequency of vaginal species of Mycoplasma genitalium, Gardnerella vaginalisand Neisseria gonorrhoeaeamong pregnant women by PCR technique. Int J Mol Clin Microbiol. 2013;1(3):231-6.

41. Ahmadi A, Khodabandehloo M, Ramazanzadeh R, Farhadifar F, Nikkhoo B, Soofizade N, et al. Association between Ureaplasma urealyticum endocervical infection and spontaneous abortion. Iran J Microbiol. 2014; 6(6):392-7.

42. Mousavi A, Farhadifar F, Mirnejad R, Ramazanzadeh R. Detection of genital mycoplasma infections among infertile females by multiplex PCR. Iran J Microbiol. 2014;6(6):398-403.

43. Jamalizadeh Bahaabadi S, Mohseni Moghadam N, Kheirkhah B, Farsinejad A, Habibzadeh V. Isolation and molecular identification of Mycoplasma hominis in infertile female and male reproductive system. Nephrourol Mon. 2014; 6(6):e22390 Available from: http://www.pubmedcentral.nih.gov/articlerender. fcgi?artid=4330675\&tool=pmcentrez\&rendertype=abstract.

44. Sobouti B, Fallah S, Mobayen M, Noorbakhsh S, Ghavami Y. Colonization of Mycoplasma hominis and Ureaplasma urealyticum in pregnant women and their transmission to offspring. Iran J Microbiol. 2014;6(4):219-24.

45. Dadashi M, Eslami G, Ghalavand Z, Goudarzi H, Fallah F, Owlia P. Prevalence of Chlamydia trachomatis and Mycoplasma genitalium in patients with Benign and malignant ovarian cancer by nested PCR method. Novel Biomed. 2016:4(1):18-23. 
46. Eslami G, Goudarzi H, Baseri N, Ghalavand Z, Taherpour A, Zhaam H. The prevalence of Ureaplasma urealyticum and Mycoplasma genitalium in patients with prostate cancer in Shohada Hospital in Tehran, Iran. Novel Biomed. 2015;3(2):73-8.

47. Safavifar F, Bandehpour M, Hosseiny SJ, Khorramizadeh MR. Mycoplasma infection in Pyospermic infertile and healthy fertile men. Nov Biomed. 2015;3(1):25-9.

48. Safari M, Bakhshi A, Erami M, Kheirkhah B, Pourbakhsh A, Pourbabei H. Sequences of Mycoplasma hominis in patients with urinary tract infection in a Hospital in Kashan, Iran. Res J Microbiol. 2015;10(6):260-9 Available from: http://www.scialert.net/abstract/?doi=jm.2015.260.269.

49. Ramazanzadeh R, Khodabandehloo M, Farhadifar F, Rouhi S, Ahmadi A, Menbari S, et al. A case-control study on the relationship between Mycoplasma genitalium infection in women with Normal pregnancy and spontaneous abortion using polymerase chain reaction. Osong Public Heal Res Perspect. 2016;7(5):334-8 Available from: https://doi.org/10.1016/j.phrp. 2016.07.001

50. Ahmadi MH, Mirsalehian A, Sadighi Gilani MA, Bahador A, Talebi M. Asymptomatic infection with Mycoplasma hominis negatively affects semen parameters and leads to male infertility as confirmed by improved semen parameters after antibiotic treatment. Urology. 2017;100:97-102 Available from: https://doi.org/10.1016/j.urology.2016.11.018.

51. Bahrami H, Farivar TN, Aslanimehr M, Peymani A, Dabaghi T, Ghaleh T, et al. Prevalence of Ureaplasma urealyticum in Endocervical Specimens of Female Patients in Qazvin, Iran. BiotechHealth Sci. 2016;3(4):e39599.

52. Asgari A, Nazari R, Mohammad S, Razavian H. Investigation of frequency of Mycoplasma hominis and biological parameters in semen sample of men referred to Qom Jahad Daneshgahi infertility treatment center in 2016. Qom Univ Med Sci J. 2018;12(4):81-8.

53. Irajian G, Sharifi M, Mirkalantari S, Mirnejad R, Jalali Nadoushan MR Molecular detection of Ureaplasma urealyticum from prostate tissues using PCR-RFLP, Tehran, Iran. Iran J Pathol. 2016;11(2):138-43.

54. Sameni F, Zadehmodarres S, Dabiri H. Prevalence of Chlamydia Trachomatis -Mycoplasma genitalium and Neisseria gonorrhea in infertile females referred to Mahdieh hospital in Tehran. Iran J Med Microbiol. 2017;11(5):90-7.

55. Javadinia S, Movahedi Z, Shokrollahi MR, Naghdalipour M, Tabatabaee A, Asgarian $\mathrm{R}$, et al. Prevalence of Mycoplasma genitalium and Ureaplasma urealyticum in pregnant women of Tehran by duplex PCR. Curr Pediatr Res. 2017;21(4):680-5.

56. Golkhatmi Mokari A, Farsiani H, Goshayeshi L, Radmanesh H, Jamehdar AS. Development of PCR-ELISA for specific and sensitive detection of Mycoplasma genitalium. Clin Microbiol. 2017;6(1):1.

57. Moradi F, Yousefi MR. Comparison of PCR and culture methods to determine the prevalence of Mycoplasma hominis in woman's endocervical samples referred to Infertility Center of Hamadan Fatemieh Hospital in 2016. IJOGI. 2018;20(11):83-92.

58. Cabral SLI. Genetic variation in Mycoplasma genitalium. In: Antigenic diversity and persistence of infection within a genomically challenged pathogen. ProQuest; 2008.

59. Cazanave C, Charron A, Renaudin H, Bébéar C. Method comparison for molecular typing of French and Tunisian Mycoplasma genitalium-positive specimens. J Med Microbiol. 2012;61(4):500-6.

60. Jensen JS, Cusini M, Gomberg M, Moi H. 2016 European guideline on Mycoplasma genitalium infections. J Eur Acad Dermatol Venereol. 2016; 30(10):1650-6.

61. Horner PJ, Blee K, Falk L, van der Meijden W, Moi H. European guideline on the management of non-gonococcal urethritis. Int J STD AIDS. 2016;27(11):928.

62. Munoz $J$ L, Goje OJ. Mycoplasma genitalium: an emerging sexually transmitted infection. Scientifica (Cairo). 2012;2016(December):942-55 Available from: https://www.scopus.com/inward/record.uri?eid=2-s2.0-8501 $9115353 \&$ doi $=10.1155 \% 2$ F2016\%2F7537318\&partnerlD=40\&md5=61 dfd 6 c5 e393f35d2bef0d22667a9056.

63. Oakeshott P, Aghaizu A, Hay P, Reid F, Kerry S, Atherton H, et al. Is Mycoplasma genitalium in women the "new chlamydia?" a communitybased prospective cohort study. Clin Infect Dis. 2010;51(10):1160-6.

64. Lee MY, Kim MH, Lee WI, Kang SY, La JY. Prevalence and antibiotic susceptibility of Mycoplasma hominis and Ureaplasma urealyticum in pregnant women. Int J Infect Dis. 2010;57(14):e90-5 Available from: https:// doi.org/10.1016/j.jijid.2009.03.020.

65. Taylor-Robinson D. Infections due to species of Mycoplasma and Ureaplasma: an update. Clin Infect Dis. 1996;23(4):671-84.
66. Embree JE, Embil JA. Mycoplasmas in diseases of humans. Can Med Assoc J. 1980;123(2):105-11 Available from: http://www.ncbi.n/m.nih.gov/pmc/ articles/PMC1704661/\%0A, http://www.ncbi.nlm.nih.gov/pmc/articles/PMC1 704661/pdf/canmedaj01462-0025.pdf.

67. Ghorbanalinezhad E, Amirmozafari N, Khavari-nejad R, Sepahi AA. International journal of molecular and clinical microbiology survey on the genital mycoplasmosis by multiplex PCR, vol. 2; 2014. p. 451-6.

68. Ghadiri A, Ahmadi K, Rashno M, Moosavian M, Afzali M, Amirzadeh S. Investigating Chlamydia trachomatis and genital Mycoplasma prevalence and apoptosis markers in infertile and fertile couples. Jundishapur J Microbiol. 2019;12(1):1-7.

69. Leli C, Mencacci A, Latino MA, Clerici P, Rassu M, Perito S, et al. Prevalence of cervical colonization by Ureaplasma parvum, Ureaplasma urealyticum, Mycoplasma hominis and Mycoplasma genitalium in childbearing age women by a commercially available multiplex real-time PCR: an Italian observational multicentre study. J Microbiol Immunol Infect. 2018;51(2):2205 Available from: https://doi.org/10.1016/j.jmii.2017.05.004.

70. Zhu X, Li M, Cao H, Yang X, Zhang C. Epidemiology of Ureaplasma urealyticum and Mycoplasma hominis in the semen of male outpatients with reproductive disorders. Exp Ther Med. 2016;12(2):1165-70.

71. Mahlangu MP, Müller EE, Venter JME, Maseko DV, Kularatne RS. The prevalence of Mycoplasma genitalium and association with human immunodeficiency virus infection in symptomatic patients, Johannesburg, South Africa, 2007-2014. Sex Transm Dis. 2019:46(6):395-9.

72. Baumann L, Cina M, Egli-Gany D, Goutaki M, Halbeisen FS, Lohrer GR, et al. Prevalence of Mycoplasma genitalium in different population groups: systematic review andmeta-analysis. Sex Transm Infect. 2018;94(4):255-62.

73. Huang C, Zhu HL, Xu KR, Wang SY, Fan LQ, Zhu WB. Mycoplasma and ureaplasma infection and male infertility: a systematic review and metaanalysis. Andrology. 2015;3(5):809-16.

74. Kasprzykowska U, Sobieszczańska B, Duda-Madej A, Secewicz A, Nowicka J, Gościniak G. A twelve-year retrospective analysis of prevalence and antimicrobial susceptibility patterns of Ureaplasma spp. and Mycoplasma hominis in the province of lower Silesia in Poland. Eur J Obstet Gynecol Reprod Biol. 2018;220:44-9.

75. Cassell GH, Waites KB, Watson HL, Crouse DT, Harasawa R. Ureaplasma urealyticum intrauterine infection: role in prematurity and disease in newborns. Clin Microbiol Rev. 1993;6(1):69-87.

76. Zinzendorf NY, Kouassi-Agbessi BT, Lathro JS, Don C, Kouadio L, Loukou YG. Ureaplasma urealyticum or Mycoplasma hominis infections and semen quality of infertile men in Abidjan. J Reprod Contracept. 2008;19(2):65-72.

77. Taken K. Prevalence of Ureaplasma and Mycoplasma in infertile men in Van region and effects to semen parameters. J Clin Anal Med [Internet]. 2016; 7(3):4-7 Available from: http://www.jcam.com.tr/files/KATD-2668.pdf.

78. Abusarah EA, Awwad ZM, Charvalos E, Shehabi AA. Molecular detection of potential sexually transmitted pathogens in semen and urine specimens of infertile and fertile males. Diagn Microbiol Infect Dis. 2013;77(4):283-6 Available from: https://doi.org/10.1016/j.diagmicrobio.2013.05.018.

79. Jensen JS, Hansen HT, Seruminstitut S. S D-C. isolation of Mycoplasma genitalium strains from the male urethra. Microbiology. 1996;34(2):286-91.

80. Al-Sweih NA, Al-Fadli AH, Omu AE, Rotimi VO. Prevalence of Chlamydia trachomatis, Mycoplasma hominis, Mycoplasma genitalium, and Ureaplasma urealyticum infections and seminal quality in infertile and fertile men in Kuwait. J Androl. 2012;33:1323-9.

81. Lee JS, Kim KT, Lee HS, Yang KM, Seo JT, Choe JH. Concordance of Ureaplasma urealyticum and Mycoplasma hominis in infertile couples: impact on semen parameters. Urology. 2013;81(6):1219-24 Available from: https:// doi.org/10.1016/j.urology.2013.02.044.

82. Andersen B, Sokolowski I, Østergaard L, Kjølseth Møller J, Olesen F, Jensen JS. Mycoplasma genitalium: prevalence and behavioural risk factors in the general population. Sex Transm Infect. 2007;83(3):237-41 Available from: http://sti.bmj.com/cgi/doi/10.1136/sti.2006.022970\%0A, http://www.ncbi.nlm. nih.gov/pubmed/17090566\%0A, http://www.pubmedcentral.nih.gov/ articlerender.fcgi?artid=PMC2659104.

83. Grześko J, Elias M, Maczyńska B, Kasprzykowska U, Tłaczała M, Goluda M. Occurrence of Mycoplasma genitalium in fertile and infertile women. Fertil Steril. 2009;91(6):2376-80.

\section{Publisher's Note}

Springer Nature remains neutral with regard to jurisdictional claims in published maps and institutional affiliations. 